\title{
Past the Kalashnikov: Youth, Politics and the State in Eritrea
}

\author{
Sara Rich Dorman \\ School of Social and Political Studies,Edinburgh \\ sara.dorman@ed.ac.uk
}

The spirit of youth is just incredible... almost every tegadelai [fighter] accepts martyrdom as an inevitable outcome of his or her love and loyalty to country and cause. But, our youth go far beyond that...especially now that they are about to go to the place of their dreams, the frontline....

...kids in their late teens and early twenties have turned courage into a norm. Death is being defied as it is just a hurdle to jump over, as if it is not the end of a person's journey...they have this unflinching conviction that they will live on in their surviving comrades, in the realization of the dream they are dying for.

Alemseged Tesfai, Two Weeks in the Trenches pp46-7, 50.

\section{INTRODUCTION}

Alemseged Tesfai's war diary captures both the ethos of the Eritrean liberation war and of the young fighters he was observing in 1985. Six years afterwards, the Eritrean People's Liberation Front (EPLF) fought the last battle of the independence struggle, and marched into Asmara, the capital of Eritrea. Given the iconic nature of the thirty-year struggle to liberate Eritrea, the post-liberation state has been marked by the ethos of youthful sacrifice captured above. Martyrdom was an inevitable outcome of liberation (Tesfai 2002: 46); no one died; they simply became a martyr (Bereketeab 2000: 232). Eritrea's current generation of youth bears much of the weight of this inheritance, under very different circumstances than previous generations.

Like other post-liberation states such as Zimbabwe, South Africa, Namibia, Mozambique and Uganda, Eritrea has faced two 'transitional' challenges: how to transform a colonized and war-stricken economy and how the former liberation movement should relate to the citizens of the new state. While Eritrea's solutions have been similar to those of other newly independent African states, they have also had 
distinctive features. The goal of this paper is to consider the particular dynamics of Eritrean politics through an examination of the relationship between youth and the state, which is not merely typical of state-society relations, but constitutive of Eritrean identity and nationalism. Since the summer of 2001, Eritrean youth have been at the centre of interlinked political crises. The rejection, by some youth, of societal and state expectations that they will 'serve the nation' challenges the post-liberation political culture and institutions.

\section{YOUTH AND THE STATE 1991-2001}

The politics of Eritrea's youth has so far been described mainly in unpublished material by students and recent graduates of the University of Asmara (Ahmed 2000; Gebregiorgis 2001). In a recent paper, I investigated how post-liberation shifts have obligated the youth organization to transform itself into something resembling a traditional NGO (Dorman 2002). Little other sector-specific research has been carried out, with the exceptions of gender (Bernal 2000, Forthcoming), literature (Negash 1999), language (Hailemariam 2002; Woldemikael 2003), and education (Gottesman 1998; Bjorndal 2003).

Academic research on the broader topic of state-society relations in Eritrea has emphasized debates about development policy, political parties, and the constitution, and tended, at least until 1998, to be 'cautiously optimistic' (Iyob 1997). Fouad Makki's 'reasoned optimism'(Makki 1996: 496) led him to predict that the 'juridical and political framework' designed under the new constitution, would subject the PFDJ to 'a healthy contestation for hegemony' which would create 'national political pluralism' (Makki 1996: 490). In a short but detailed consideration of the post-independence regime, Dan Connell argued in some detail that it is not anti-pluralist, but rather open to societal participation (Connell 2000). Sadly, this optimism, based on the emergent independent press and the enthusiasm of social movements, seems to have been misplaced. As will be discussed in more detail below, since the 1998-2000 war between Eritrea and Ethiopia, democratisation has gone seriously off-track. 
Nevertheless, we can make some preliminary comments on the state and nationbuilding process, and how it has affected the formation and development of social organizations. Ruth Iyob described the post-independence politics as representing a 'politics of inclusion' because of the regime's willingness to re-incorporate old rivals into government (Iyob 1997: 665). We can extend this idea of 'inclusion' to reflect also the politicians' approach to 'non-political' associations, which are expected to work cooperatively with the state, as they did the nationalist movement (Dorman 2003).

As Fouad Makki noted, in Eritrea the "political and cultural project" of nationalism "found practical embodiment primarily within the liberation movements.....In the absence of a civil society that could monitor and steer their dynamics, the liberation movements developed an autonomous and somewhat substitutionist political culture."(Makki 1996: 477) The implications of this are obvious: "the hierarchical organizational frames encouraged a compliant culture in which the ideal of a self-empowering citizenry was somewhat restricted."(Makki 1996: 477) In practice, this has meant that "after liberation many people, long accustomed to strict controls under Ethiopian occupation or to the highly centralized war-time structures of the EPLF, appeared hesitant to start new organizations outside the control of the liberation movement."(Connell 1997: 152) While Eritrea is best known for its restrictions on international NGOs, the restraints on local NGOs are at least as constricting. There are presently only 14 local NGOs operating in Eritrea, three of which are the former EPLF mass organizations (Abraham 2002). Eleven years after de-facto independence, Eritrea is arguably Africa's least plural society. ${ }^{1}$

\section{Limited Pluralism and Youth Organisation}

One legacy of the liberation war for state-society relations has been the close relationship between the former mass organizations and the new state. Young people and students were at the heart of early uprisings in Asmara against the Ethiopian regime. Members of the ELF and EPLF, including Isaias Afewerki, emerged out of the students' movements

\footnotetext{
${ }^{1}$ While Eritrea's 'front-led government' can be usefully compared to the NRM in Uganda, it lacks the latter's mitigating decentralization, pluralism and independent press. On the importance of decentralization in Uganda see, Martin Doornbus, "African multi-partyism and the Quest for Democratic Alternatives" in Jon Abbink and Gert Hesseling eds. Election Observation and Democratization in Africa (London: Macmillan, 2000), pages 99-121.
} 
in Asmara, Addis Ababa and Cairo (Ammar 1997). As the struggle went on, youth associations formed in Egypt, the Sudan and further abroad as recruiters and fund-raisers for the struggle. In 1978 the youth movement became a formal part of the EPLF, along with associations of women and workers.

Most liberation movements attempted to subsume societal bases under them. The Eritrean People's Liberation Forces (EPLF) seems to have succeeded to an unusual degree, perhaps because of the particularly unpromising conditions of their struggle. This contrasts with the situation in Zimbabwe and South Africa, where the multiplicity of liberation forces meant that internal and diaspora groups supported 'liberation' rather than being formally part of particular parties. In Namibia, the youth movement affiliated with SWAPO only very late in the process, just before independence, and disaffiliated shortly thereafter (Maseko 1995: 115-116, 126-127).

In Eritrea, not only did the mass organizations come under the jurisdiction of the liberation movement during the struggle, but they also resisted disengagement after independence was achieved. In 1992, the EPLF declared that the mass organizations must become independent. This declaration was unexpected and proved difficult to implement for the National Union of Eritrean Youths and Students (NUEYS). As one long-time member said, "We are [were] proud to be members of EPLF, but after the independence the government declared that the organization would be non-governmental, so for me this was strange."(Fessehaye 2002 int.) At their 1994 congress, NUEYS members voiced their bewilderment. As the press reported,

As far as the Union's links with the PFDJ was concerned, there was some debate as to the extent of close political ties. Union chairman, Muheiddin Shengeb, said that free association is not a matter of choice. In 1992 the government decreed that mass organizations have to be independent.... (Eritrea Profile 3.9.1994)

Although the official line is clear: "It certainly is an independent union....If we have close relations with PFDJ it is because we have unity of aim," (Eritrea Profile 24.1.1998), NUEYS staff and senior leadership recognise and admit the ambiguity of their relationship with the party. As the chairman said, shaking his head in amusement: 
We always talk to them and still they are not clear...we share history and culture and there should be values in common...we are not yet clear...this is the question that always remains without a full answer (Shengeb 2002 int.).

Despite this candour, his reference to 'them' is somewhat misleading, as he himself is a member of the PFDJ's executive committee.

Whatever the actual status and relationship between NUEYS and the ruling party, it is important to note that NUEYS is one of the most significant non-governmental organizations in Eritrea. Dan Connell, who has written extensively about the EPLF and the mass organizations, described NUEYS as "the fastest growing, the feistiest, and the most campaign oriented of the sectoral associations" (Connell 1997: 151). NUEYS is also the only apparent group working with young people in Eritrea, all school based groups, including Scouts, are subsumed into their structures.

Pluralism in Eritrea, fairly limited since independence, became more constricted after the 1998-2000 war with Ethiopia. In 2001, Eritrea was convulsed by a political debate in which high-profile members of the ruling People's Front for Democracy and Justice (PFDJ), called for internal party reform, the implementation of the 1997 constitution, and the holding of national elections (Sherifo 2001). Discussion percolated briefly in government and independent newspapers (including those of the youth movement) until September 2001, when the leading critics and journalists were detained, and the newspapers were closed down (Plaut 2002). Two and a half years later, no charges have been laid against those detained, no national elections have been held, and the constitution remains unimplemented.

\section{Mobilization and the role of youth}

A second legacy of the liberation war has been an emphasis on social mobilization. Drawing on the traditions of the fighters, many of whom continued to work as volunteers after independence in 1991, national service for all was introduced in 1994 (Eritrea Profile 4.6.1994) and written into the 1997 constitution (The Constitution of Eritrea 1997: article 25.3). It was designed to create a trained reserve army, connect young people to the older, liberation-war generation, and to develop cross-cultural understanding by integrating the different ethnic groups and religions (Bereketeab 2004). 
Although Eritreans see these concerns as particularly important for Eritrea's ethnically, religiously and linguistically plural society, similar concerns were voiced by other new independent African states, when launching their prototypical national service schemes in the 1960s (Callaway 1963).

The programme involved all 'youth' between the ages of 18 and 40 training at the Sawa Military Camp for 6 months (military service), followed by 12 months of work in various ministries (national service) at a nominal wage. Young people on national service were being paid Nakfa 145 (USD 10), recently increased to Nakfa 500 (USD 30) per month. Although Bereketeab (2004) has noted that this small amount of money may have a profound transformative effect in rural areas, this is not a salary that one can live on in urban areas, especially if one has a family, or needs to pay rent. National Service employees at the university referred to it derisorily as 'pocket money'. Rural families are, of course, also affected by the loss of man-power, especially for plowing and at harvest-times.

In 1998, a National Development Campaign was briefly implemented, which called upon all of those who had participated in National Service since 1994 to remobilize for one month and carry out development projects. The programme, designed to mobilize 50 - 60000 Eritreans, was scheduled to start at the end of April and to continue through May (Eritrea Profile, 21.3. 1998, 14.3. 1998). When the border war started in mid-May, the development projects were abandoned but the already mobilized youth were transferred to the front, along with remobilized veterans (Eritrea Profile 13.6.1998, 10.10.1998). Since then national service has become a permanent condition for the nation's 'youth'. With those who have turned 40 since 1998 not yet excused, multiple generations of families serve together. The warsai-yikealo ${ }^{2}$ initiative, launched in 2002, is thought to extend national service commitments for at least another two years, as conscripts are mobilized to rebuild Eritrea's shattered economy (Eritrea Profile 11.5.2002; Hadas Ertra 16.7.2002).

Although these campaigns are thought of as 'voluntary' and encouraging 'selfsacrifice,' in practice they are tightly controlled. In an interview, President Isaias

\footnotetext{
${ }^{2}$ Warsai-yikealo is usually translated as 'old and new fighters'; it is intended to symbolize the continuity between the older generation of fighters from the liberation war, and those who fought from 1998 onwards.
} 
emphasized, "Everybody recruited for national service has to go. As for those who create lame excuses for not going, let them know that there is no way one can evade it." (Eritrea Profile 7.3.1998). The irony is that in 1994, during a public meeting called in response to fears that "the N[ational] S[ervice] P[rogramme] will not end in 18 months. We are going to replace the demobilized army" President Isaias said, "There is no derg here (during the derg conscripts were forced to service for an indefinite period) the NSP lasts for 18 Months and not a day longer. The Ministry of Defence has a separate programme for recruiting a standing army" (Eritrea Profile 4.6.1994).

Youth, the military, service and sacrifice are symbolically linked in Eritrea's political culture. Alemseged Tesfai's memoirs, quoted at the start of this article, give a sense of how youth was portrayed in the liberation struggle. These images are also imprinted on the urban fabric in murals, shop-front displays, and public monuments. Since the 1998-2000 war, similar images have appeared, depicting the new, young generation of fighters (see Appendix). In 2002, an exhibition of artwork and inventions by Eritrean youth, was opened by President Afewerki ceremonially raising a boom modeled to resemble a giant Kalashnikov. Like the youth, who must shoulder the Kalashnikov to become part of the nation, participants passed under the symbolic reminder of a state created through and by military force.

\section{TWO POLITICAL CRISES ${ }^{3}$}

In the summer of 2001, Eritrea moved slowly into a political crisis, which coalesced around the notion of 'service', linked to, but also distinct from, that catalysed by the G15.

Crisis 1: Summer Work Programmes

\footnotetext{
${ }^{3}$ Conducting research in Eritrea is subject to many constraints. I was able to interview many NUEYS members and staff as part of another research project in the summer of 2002. In discussing the issues of national service, and the events of August 2001 with students, colleagues, and acquaintances, I avoided formal interviews, and have maintained the confidentiality of all my contacts. Eritrea Profile and Hadas Ertra are publications of the Ministry of Information, and much of their content can be taken to be formal statements of government policy. In the interests of transparency, I have attempted to provide sources for other allegations and statements, many of which circulated widely within and outside Eritrea, even where those sources may be biased or politically-influenced.
} 
In 1994, when military service was introduced for high school graduates, a student work programme for secondary school students was also initiated under the auspices of the Ministry of Education (Eritrea Profile 25.6.1994, 28.7.1997). These have become a staple part of student life - each year the media reports how many seedlings have been planted, how many metres of terraces constructed, how many irrigation canals dug over the summer break. Since 1999 to 2001, University students were also expected to spend their summer vacations in work programmes.

In July 2001 the president of the University of Asmara student union, Semere Kesete used the well-publicized occasion of graduation to criticize the expectation that University students would spend their summers on the work programme, and the conditions of those programmes. The University, for its part, suggested that the summer programmes were expected because the University had waived national service for the students, and that they were willing to negotiate over the conditions and type of work (Eritrea Profile, 25.8.2001).

Soon after this speech, Semere was detained and imprisoned in solitary confinement.. Student protesters outside the court were arrested and detained in the National Stadium. Parents who demonstrated against the detention of their children were dispersed (Chronicle, 21.8.2001). The students - including those who were arrested were sent to a forced work camp in the area bordering on the Red Sea, near the Danakil depression which is nearly inhabitable in the summer months. Two students died of heatstroke, and the rest were only allowed to return to studies in Asmara after the intervention of the University President (awate.com 1.8.2001, 20.8.2001).

Semere Kesete remained in solitary confinement, with no access to his family or lawyers, until almost exactly a year after his detention, he and one of his guards - a young ex-fighter - apparently escaped and fled to Ethiopia (BBC 9.8.2002).

Throughout these events, the association of youths and students was either silent, or intervened on the side of the government. This has been interpreted as a political move. One former student leader said, "they are merely interested in signally to the executive that they are prepared to succeed them". Yet, from a less cynical perspective, we can see this situation as capturing the central dilemma of NUEYS. Existing firmly within Eritrea's nationalist culture which reifies 'sacrifice,' NUEYS appeals to youth to 
provide volunteer service is one of it defining characteristics: "Eritrean youth is the bearer of responsibility"(NUEYS 2000: 10) As a University student said to me:

As members of NUEYS we believe we should do things for free. Members of the student union at the university claimed that if you do service, you should be paid.

NUEYS leadership actually claims that the 'volunteer' initiatives which so dominate current Eritrean life were originated by them. As the Chairman reported in an interview on ERI-TV, later transcribed in the press:

...programs which involve the youth such as the National Service Program, the Summer Work Program, and the National Development Campaign are basically initiated by NUEYS. The National Service Program was proclaimed by the union in its 1981 congress. The Summer Work Program was initiated in the 80s. Eritrean youths used to serve the revolution during their spare time in summer. The youth have participated in collecting cotton....and constructing building complexes...before the National Service Program was launched in 1992-3 (Eritrea Profile, 10.10. 1998).

NUEYS has chosen to portray the student's resistance to engaging in the summer work programme as the machinations of 'an enemy' rather than as a independently derived rejection of national policy.

NUEYS has seen the university student union as a rival for some time, because the university had refused to allow NUEYS to organize a branch or open an office on campus. NUEYS thinks that they were discouraged from organizing university youth, because they are too strong, suggesting that the university wanted a more easily influenced group of students, in an autonomous union, which would not have outside sources of strength. ${ }^{4}$ Nevertheless, NUEYS say it as a direct challenge to their representation of youths:

They see NUEYS as structured from outside. Allowing us to have a branch within the university would have interfered... they said you can work in university but you cannot have a branch. Maybe they think, if you have a branch, the university administration might feel not at ease. I think that the

\footnotetext{
${ }^{4}$ Ironically, one university staff member suggested to me that the students union had in fact been created as a balance to faculty demands for a staff union.
} 
main reason it is about power. We are seen as too powerful, in contrast with university...(Shengeb 2002)

In contrast, university administrators, although extremely reluctant to discuss the case, suggest that it is because NUEYS are 'too political': "Maybe we don't want to have these political associations on campus." Or as another former administrator said, emphasizing that this was a personal, and not an official opinion: "If there is only one party, How can we let this group influence the students? Under the Derg, there was a similar union that was always interfering in our activities, so when this group comes, we think, we don't want them interfering in our activities."

In the 2001 annual report, NUEYS vented its frustrations over being blocked from the campus:

NUEYS was kept at a distance, only to watch, instead of working with the university to cultivate the youth and to solve their problems. In contrast, the campus was a convenient forum for religious and other political activists to spread their out-dated ideas (NUEYS 2002).

The University of Asmara students are represented as manipulated by the G-15:

...all this was a political movement by a few students with a hidden political mission, trying to exploit the economic problems of the student masses....as it carefully watched this destructive and anti-national interest movement, the Union condemned it.(NUEYS 2002)

In contrast, opposition websites report that NUEYS own antagonism to the G-15 has more to do with business deals than ideology. According to Awate.com:

NUEYS officials considered the G-15 as obstacles to their career goals and at least two, Brigadier General Estifanos Seyoum the former chief of the Inland Revenue Service; and Petros Solomon, former Minister of Fisheries, had objected to NUEYS refusal to pay taxes and port fees (awate.com 23.1.2002).

NUEYS was widely seen as more dogmatic and set against the reformers than many other groups in society. It was noted by many that when even state-owned newspapers avoided taking sides in what was seen as an intra-party struggle, NUEYS came out publicly against the G-15. Or, as they say themselves: 
Our newspapers worked hard in challenging the false allegations that used to be issued in the private media discourses and in preserving national unity(NUEYS 2002).

Since 2001, NUEYS has opened a "university" branch, with an office near the campus, but not in it. The branch hopes to provide access to computers and subsidized photocopiers, in addition to social and sporting activities. It has proved very popular, with 800 members joining.

\section{Crisis 2: Draft-dodging}

In the years since the cease-fire agreement with Ethiopia, there has been resistance to the military service recruitment, with young people fleeing the country illegally, hiding from soldiers, and resisting capture. Cities are surrounded by army roadblocks, where the identification papers of all passengers are checked. Those who have not 'served' cannot get exit-visas. During the annual 'gffa' or 'round-up' of draft-dodgers there are young military police on every street corner, walking up and down every street, checking documents of passers-by. The streets often appear unusually quiet, with few young people visible. In 2002, the gffa was particularly severe, with unconfirmed reports of several deaths from exchanges between parents and soldiers (awate.com 9.7.2002, 17.7.2002).

Resistance to nation service centres on reports of sexual abuse of female conscripts by senior army officers who act with impunity. Although these allegations appear to be widely believed, little evidence or first-person accounts have emerged. Two foreign journalists have reported interviewing women who claim to be rape victims from Sawa (Sette, Corriere della Sera, 26.9.2002; The Age 05.12.2002), but their information has not been verified by other sources. Young women are reported to seek consensual sexual relationships with their peers, in the hopes that they will become pregnant, marry, and avoid potential rape. This may also be their best chance of marriage, as young men say that they will not consider marrying women who have attended Sawa Military Camp because of the 'damage' done to them there.

University graduates resent being paid only Nakfa 500, and having little choice in their post-graduate employment or training. In 2003, the previous year's university 
graduates were sent to Sawa to teach in the new 'Warsai-Yikealo' high school offering final year courses for all students, preparatory to attending University, or entering the National Service programme (IRIN 13.11.2002). Graduates sent abroad to study complain that they were given little warning of their destinations, and no choice about their degree programmes (Mekonnen et al. 2004).

In August and September of 2002, there were also frequent reports of Eritreans deserting to neighbouring countries. For example, in August, it was reported that 122 Eritreans had fled to Ethiopia. In a typical report, compiled from the Ethiopian press (which is vehemently anti-Eritrean), it was claimed that 14 students and 3 soldiers had arrived in Mekelle, the capital of Tigray province (AGP, 29.8.2002). Or, as on 2 October that 39 members of the navy had fled to Yemen (Walta 2.10.2002). While these reports must be read with caution - emanating as they do from hostile sources - interviews on Ethiopian radio and TV (received on satellite in Eritrea) with these escapees do add veracity. Even more intriguing was a report from UNHCR that a refugee camp in Ethiopia, set up to accommodate ethnic Kunama refugees from the border war, now shelters 960 non-Kunama refugees who have arrived in the past year - over 200 in October and November of 2002. These new refugees are described by camp officials as 'mostly young men' - draft dodgers and army deserters (IRIN 22.11.2002).

\section{CONCLUSION}

Despite this recent, and limited, resistance, Eritrea's ability to allocate workers, to generate compliance with regulations, and to restrict exit visas, must position it among the strongest states in Africa. While the state's strength has historically derived from the remarkably legitimacy of the liberation movement, the brief moment of opening in 2001 revealed dissension in the ranks. President Isaias' ability to re-assert control, stifling prominent opponents, revealed a willingness to use the state's coercive apparatus against those who reject the consensus.

These two factors - limited pluralism and a strong state - distinguish Eritrea from other African states. If we conceptualise interaction of state and society in Africa as a 
continuum, Eritrea appears to be at the extreme end on both societal mobilization and state-led organization. Even in contrast to other countries which have fought liberation wars, Eritrea stands out. Most African post-independence states have been characterized by 'de-mobilization', not only of ex-soldiers but also of societal groups. Proposals to 'remobilize' the youth have also been problematic, and often of limited effectiveness. In Zimbabwe oft-voiced intentions of creating national service did not become reality until 2001. In Namibia, when students were recruited for a National Youth Service Scheme in 2002, they mutinied in reaction to the poor conditions, and marched into Windhoek, demanding to see the President (The Namibian 19.8.2002).

In Eritrea, the expectation that the youth will defend the nation, and also serve the nation in peacetime, has been much more widespread. The culture of martyrdom (Tesfai 2002: 49) has proved pervasive and influential in the years since independence, reinforced by annual events, ceremonies, and remembrance. The 1998-2000 war with Ethiopia, rather than denting the enthusiasm of youth, seemed to enhance it. But the delayed demobilization of the military, and the extension of national service through the warsai-yikealo programme have enabled youth to exercise both exit options, and voice, in criticising the top-down determination of service.

The linking of citizenship and 'service' that is particularly distinctive in Eritrea, and. The refusal of Jehovah's Witnesses to participate in national service led the state to revoke their citizenship rights (Government of Eritrea 1994). Similarly, in August 2001, the University of Asmara declared, "no citizen is above the law and that students cannot change the law of the land by any sort of intimidation" (Eritrea Profile, 25.8.2001). Ruth Iyob's analysis of Eritrea as a diasporic state is pertinent here:

The identity of diaspora populations is forged in struggles for political, economic and social survival.... At times, it risks whatever democratic credentials it had built up as a champion of a victimised people as it eliminates opponents to its survival. At other times it attempts to unilaterally redefine the normative and conventional rules embedded in the international system (Iyob 2000: 661)

Iyob is concerned with how the 'diasporic state' impacts on foreign policy. But its impact on domestic policy is at least as significant. Alemseged Tesfai captures this 
dynamic in a recent reflection. He describes how during the liberation an attitude may have developed among combatants that "he or she knew best for the country and the people". And as he further noted, after a protracted liberation struggle, "a population that is thankful to its liberator is often ready to submit to his or her direction. The problem always arises when the people begin to assert their views" (Tesfai 2003: 252). In 2003, President Isaias, called on Eritreans to pay tribute to the martyrs through a "relentless commitment to the development of Eritrea" (Eritrea Profile 21.6.2003). But the youth are increasingly seeking to exercise voice and choice for themselves. The Australiabased 'Eritrean Youth Action Network' said, "The youth are not just war machines ....they are demanding education and development not war and slavery' (awate.com 8.1.2003). The issues contested are the policies of limited pluralism and social mobilization which dominate Eritrea's political landscape. Youth are not unwilling to pass through military and national service, to participate in the commemoration of martyrs, and celebrate independence, but they are increasingly unwilling to be simply foot-soldiers in the development of the nation. 


\section{REFERENCES}

Ahmed, Mustofa M Osman (2000). NUEYS and its role in Eritrean politics. Senior Research PaperDept. of Political Science, University of Asmara.

Ammar, Wolde-Yesus (1997). "The role of Asmara students in the Eritrean Nationalist Movement." Eritrean Studies Review 2(159-84).

Bereketeab, Redie (2000). Eritrea: The Making of a Nation 1890-1991, Uppsala University.

Bereketeab, Redie (2004). "Dynamics of National Service in Eritrea." News from the Nordic Africa Institute.

Bernal, Victoria (2000). "Equality to Die for? Women Guerilla Fighters and Eritrea's Cultural Revolution." Political and Legal Anthropology Review 23(2): 61-76.

Bernal, Victoria (Forthcoming). "From Warriors to Wives: Contradictions of Liberation and Development in Eritrea." Northeast African Studies.

Bjorndal, Ingunn K. Mork (2003). "We Never Felt Like Soldiers!" Education in Eritrea: From EPLF and Education to a National Culture of Education - A Hermeneutic ConversationOslo University College.

Callaway, Archibald C. (1963). "Inter-Governmental Symposium on Unemployed Youth,." Journal of Modern African Studies 1(1): 108-109.

Connell, Dan (1997). "New Challenges in Post-War Eritrea." Eritrean Studies Review 1(2): 129-159.

Connell, Dan (2000). "The importance of self-reliance: NGOs and Democracy-building in Eritrea." Middle East Report(Spring): 28-32.

The Constitution of Eritrea (1997).

Dorman, Sara Rich (2002). National Union of Eritrean Youth and Students: Constraints and Opportunities for Organizational Development. NUEYS conference on "Eritrean Youths: post-war Challenges and Expectations", Asmara, Eritrea.

Dorman, Sara Rich (2003). "From the Politics of Inclusion to the Politics of Exclusion: NGOs and the Constitutional Debate in Zimbabwe." Journal of Southern African Studies 29(4). 
Gebregiorgis, Isaias, Saba Tesfayohannes, and Daniel Gebretensae (2001). Emerging Civil Society in an Emerging State: the case of the National Union of Eritrean Youth and Students. Eritrean Studies Association, first International Conference, Asmara, Eritrea.

Gottesman, Les (1998). To Fight and Learn: The praxis and promise of literacy in Eritrea's Independence war. Lawrenceville, NJ, Red Sea.

Government of Eritrea, 1994, A Presidential Directive On Jehovah's Witnesses.

Hailemariam, Chefena (2002). Language and Education in Eritrea: a case study of language diversity, policy and practice. Amsterdam, Aksant Academic Publishers.

Iyob, Ruth (1997). "The Eritrean Experiment: a Cautious Pragmatism?" Journal of Modern African Studies 35(4): 647-673.

Iyob, Ruth (2000). "The Ethiopian-Eritrean conflict: diasporic vs. hegemonic states in the Horn of Africa, 1991-2000." Journal of Modern African Studies 38(4): 659-682.

Makki, Fouad (1996). "Nationalism, State Formation and the Public Sphere: Eritrea 1991-96." Review of African Political Economy 70.

Maseko, Sipho S. (1995). The Namibian Student Movement: its role and effects. Namibia's Liberation Struggle: the two-edged sword. C. a. J. S. S. Leys. Oxford, James Currey.

Mekonnen, Daniel R.\& Samuel B. Abraha, 2004, The Plight of Eritrean Students in South Africa.

Negash, Ghirmai (1999). A history of Tigrinya literature in Eritrea : the oral and the written 1890-1991. Leiden, Universiteit Leiden.

Nueys, 2000, Major Undertakings of NUEYS, 1992-2000.

Nueys (2002). "NUEYS Activities of 2001."

Plaut, Martin (2002). "The Birth of the Eritrean Reform Movement." ROAPE 91: 119124.

Sherifo, Mahmoud Ahmed, Haile Woldensae, Mesfin Hagos, Ogbe Abrha, Hamid Hmd, Saleh Kekya, Estifanos Seyoum, Berhane Ghebreeghzabiher, Astier Fehatsion, Mohammed Berhan Blata, Petros Solomon, Germano Nati, Beraki Gebreslassie, Adhanom Ghebremariam, Haile Menkarios (2001). Open letter to EPLF members, asmarino.com. 
Tesfai, Alemseged (2002). Two Weeks in the Trenches: reminiscences of childhood and war in Eritrea. Lawrenceville, NJ, Red Sea.

Tesfai, Alemseged (2003). "Land and Liberation in Eritrea: reflecting on the work of Lionel Cliffe." Review of African Political Economy 96: 249-254.

Woldemikael, Tekle (2003). "Language, Education and Public Policy in Eritrea." African Studies Review 46(1): 117-136.

\section{Interviews}

Abraham, Habte, Eritrean Relief and Rehabilitation Commission,3 September 2002.

Shengeb, Moheiden,NUEYS Chairman,19 August 2002.

Fessehaye, Luul, NUEYS Executive Committee Member,8 August 2002.

Newspaper articles

Awate.com, 1.8. 2001. "Asmara University Students Issue A Statement on the Arrest of their President"

Awate.com, 20.8.2001 "Death of Yemane: 'Purposely Done...to teach us a lesson"” Awate.com 17.7.2002 "Twelve Killed in Roundup ("Gffa") Clashes"

Awate.com 9.7.2002. "Intense Nighttime Roundups—“Gffa"-In Eritrea"

$B B C$ 9 8.2002 "Student's daring jailbreak in Eritrea";

Chronicle of Higher Education, 21.8.2001 "Eritrea: arrests 2000 students at U. of Asmara"

Eritrea Profile 3.9.1994, “2nd NUEYS Congress”, page 7.

Eritrea Profile, 21.5.1994, "Benefits of National Service Stressed", page 1.

Eritrea Profile, 4.6.1994, "National Service - the facts" page 4.

Eritrea Profile, 25.6.1994 “Work For Idle Hands” page 8.

Eritrea Profile 28.1.1995, 'The Law Of The Land'. Page 5. 
Eritrea Profile 28.7.1997 'Summer Student Program And National Reconstruction', Page 2.

Eritrea Profile, 24.1.1998, NUEYS: accomplishments, vision, page 7.

Eritrea Profile 7.3.1998, 'President's reply to questions from the public: part II' Page 3.

Eritrea Profile 14.3.1998 'NDC mobilization of resources' Page 2.

Eritrea Profile 21.3.1998 "Mr Sherifo explains implementation of NDC" page 2

Eritrea Profile 10.101998 'The Youth Have Become The Pride Of The Nation', Page 7.

Eritrea Profile, 11.5.2002 Nation Launches Warsay-Yikealo Campaign” page 1;

Eritrean Profile 21.6.2003 “President Isaias” Address on Martyrs day” page 3.

Hadas Ertra, 16.7.2002, "All our potential to National progress" page 2.

IRIN 22 .11.2002. "Eritrean deserters in enemy land"

Sette, Corriere della Serra, 26.9.2002 "Eritrea, gioivane e arruolata"

The Age, 05.12.2002 "When rape is a requirement of military service"

The Namibian 19.8.2002. "Disgruntled Youths want to meet President"

Walta Information Center 2.10.2002.39 members of the Eritrean navy flee to Yemen" 


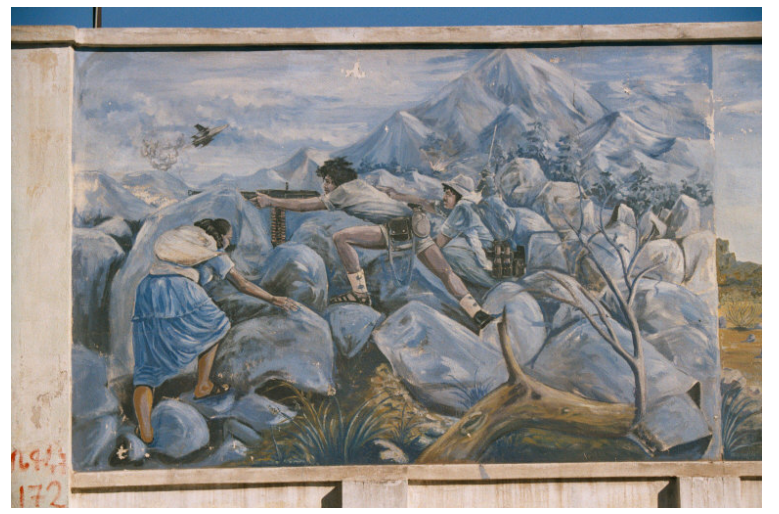

Figure 1: Excerpt of a mural in Asmara, depicting the liberation war

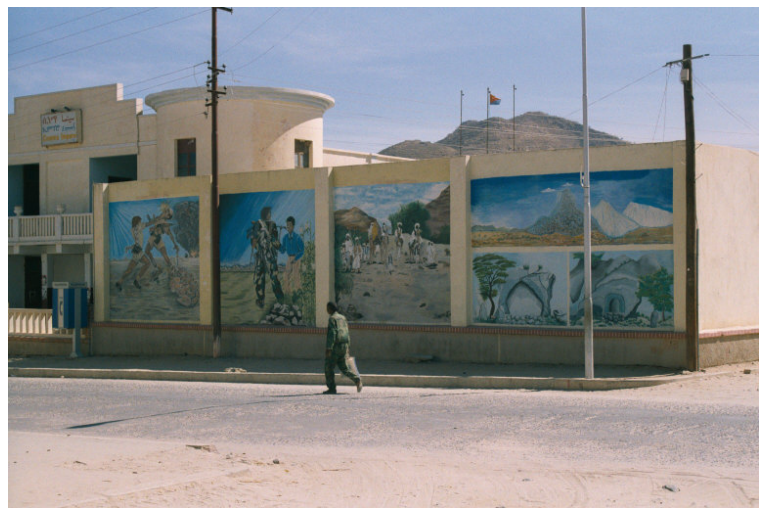

Figure 2: Mural in Keren, depicting the liberation war.

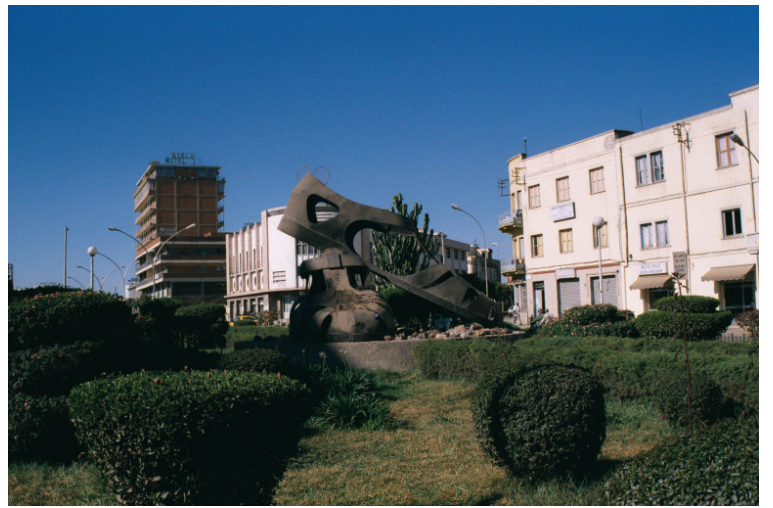

Figure 3: The famous 'shida' or sandal monument in Asmara, depicting the footgear of the EPLF fighters. Erected in 2001. 


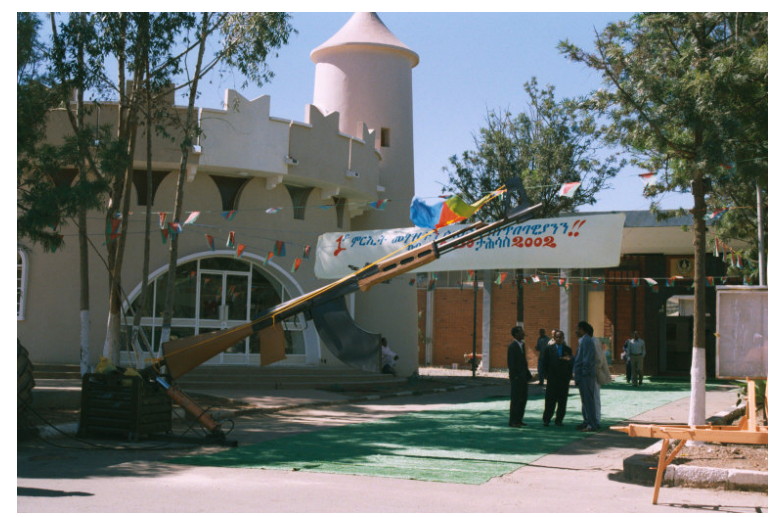

Figure 5: The 'Kalashnikov' boom at the opening of the NUEYS exhibition December 2002.
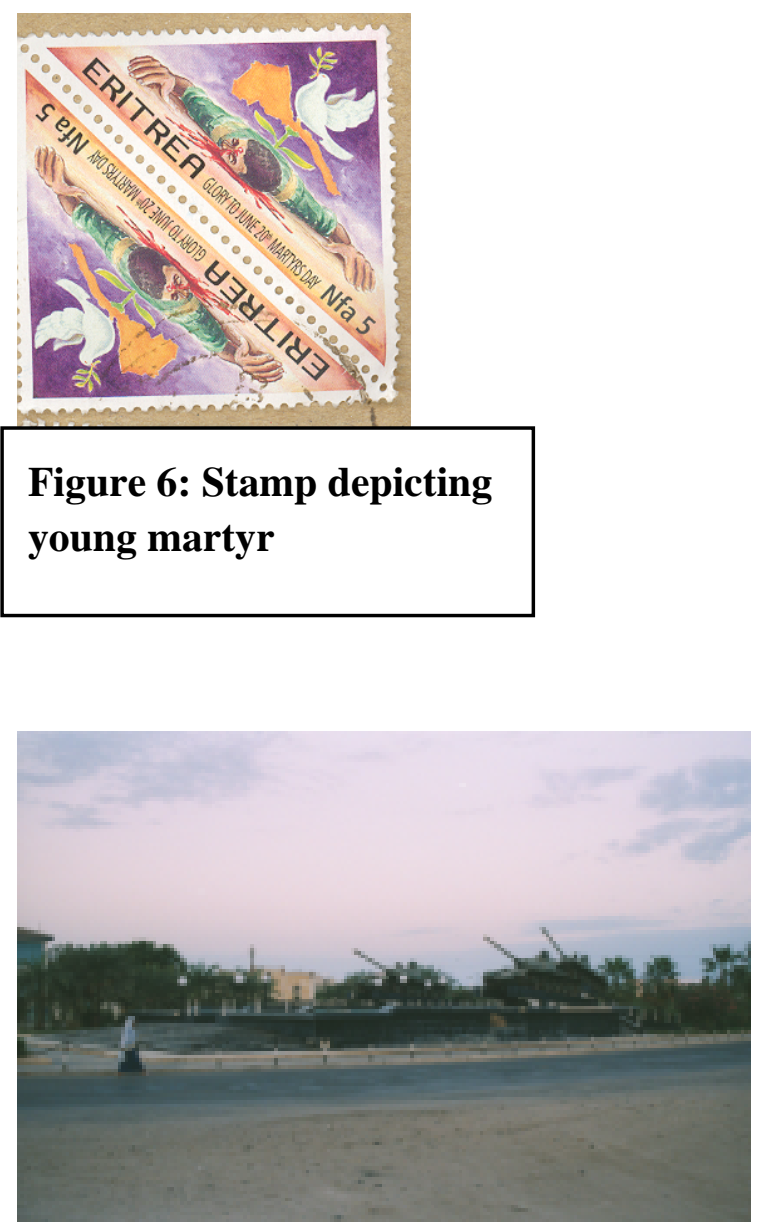

Figure 7: Tank monument (water fountain) in Massawa

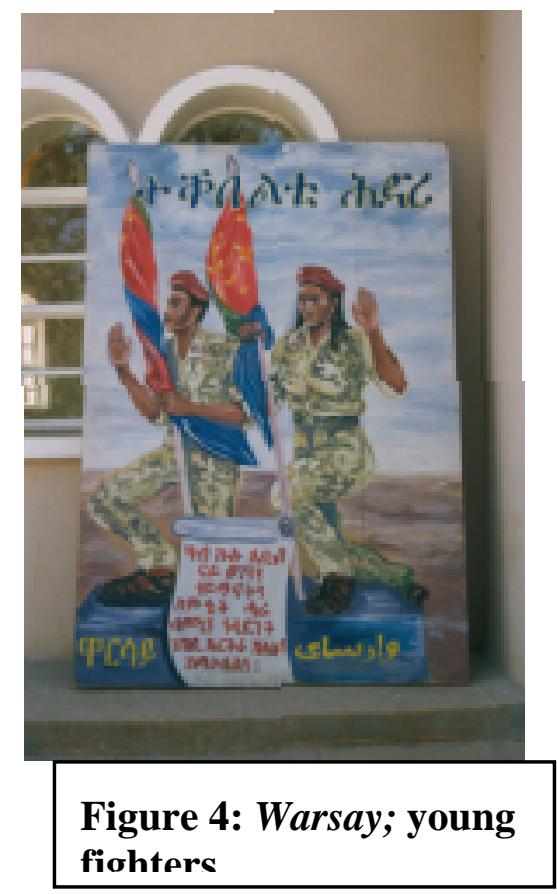

Figure 4: Warsay; young fiohterc 